\title{
Production Potential and Product Diversification to Increase Farmer's Business Capacity of Gondang Manis Rose Apple (S. Malaccense) in Jombang Regency East Java
}

\author{
Eny Diah Yuniwati \\ Faculty of Agriculture University of Wisnuwardana \\ Malang \\ nieyuniwati@gmail.com
}

\author{
Indah Prihartini \\ Faculty of Agriculture and Husbandry of University \\ Muhammadiyah Malang
}

\begin{abstract}
Gondang Manis has a potential in superior fruit quality, a high production with 3 times harvest in a year. However, economically, it has not given an impact to the farmer's earnings. The productivity of the fruit production at the age of 4 reaches $100-200$ $\mathrm{kg}$. If the average of a tree produces $200 \mathrm{~kg} /$ tree/year and the price of guava in 2016 was around $R p \mathbf{1 0 . 0 0 0}$, - per kilogram at the farmer, then one plant produces approximately Rp 2.000.000, -. Gondang Manis Rose Apple can be processed into an utilitarian food products because of its high content of vitamin $C$ and anti oxidants. The examples of processed products are syrup, juice, jam, candy jelly, sweets and ice cream. 1 $\mathrm{kg}$ of fruit produces 400 cup juice of $100 \mathrm{ml}$ with the price $R p$ 2000,- each cup. The income generated by the farmers from 1 tree increases $135 \%$ to $\mathbf{R p}$ 8.000.000. The business absorp female direct labor as well as increase the village-owned enterprise capacity building.
\end{abstract}

Keywords: Guava, Gondang Manis, Functional food

\section{INTRODUCTION}

S. malaccense is a fast-growing tree, which reaches between $12 \mathrm{~m}$ to $18 \mathrm{~m}$ when fully grown-up (Fig. 1a). It has an erect stem and pyramidal or cylindrical crown. The green leaves are the opposite, short-petiole, ellipticlanceolate or oblanceolate, they have a length of $15-45 \mathrm{~cm}$ and a width of 9 to $20 \mathrm{~cm}$. The flowers are abundant, somewhat fragrant, and are covered on the top stem; and along the adult branch is the leafless part of. The flowers grow in a cluster that runs consist of 2 to 8 in pink to dark red (Martin et al., 1987).

The fruit (figure $1 \mathrm{~b}$ ) is rectangular, obovoid or bellshaped. The length is between 5 to $10 \mathrm{~cm}$ and the width is 2 to $8 \mathrm{~cm}$. The skin is red and smooth. The fruit is white and juicy, with a sweet taste that resembles the taste of green grapes. It has a light brown seed and the diameter is around about $2 \mathrm{~cm}$. Each fruit weighs about $39 \pm 2 \mathrm{~g}$. Most of the weight comes from the flesh $(30 \pm 2$ $\mathrm{g})$, followed by seeds $(7 \pm 1 \mathrm{~g})$ and skin $(3 \pm 1 \mathrm{~g})$ (Augusta et al., 2010)

In Indonesia, the flowering phase of $S$. malaccense occurs in May and June; the fertilization is in August and September. After the flowers open perfectly, the fruit will ripe in 60 days. $S$. malaccense fruit will easily fall and break when harvested. $S$. malaccense is not a source of vitamins, but the B1 and B2 vitamins can be compared with the fruit in general. The flesh of guava can reach 75\% (Fernandes and Rodriges, 2018). Batista's research (2017) about the content of phenolite, caratenoit and antioxidants showed that the content of bioactive compounds in the fruit can be correlated with hydrophilic antioxidants.

Agustina, et al (2010) reported in her study, $8.05 \%$ consists of rind and fiber-rich $(9.34 \mathrm{~g} .100 \mathrm{~g}-1)$, vitamin C (292.59 mg.100 g-1), and anthocyanin (300.54 mg.100 g1 skin). The $\mathrm{pH}$ value of 3.5 allows it to be categorized as a highly acidic food and suitable for jam, or juice to improve the crops. Syzygium malaccense shows a physical characteristic that make it industrial for fresh fruit, juices, jams, nectar and ice cream, and its skin shows a physical and chemical property that allow it to be used as a food and dye antioxidants and also to enrich diet. Based on these, by knowing the potential of Rose Apple fruit with Syzygium malaccense in Jombang Regency, it will help to increase the selling value and increase the economic value for the rose apple farmers.

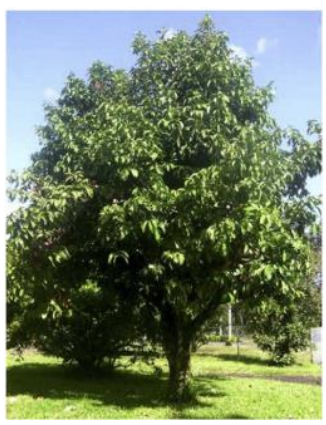

Figure 1. Tree (1a) and fruit (1b) Syzygium malaccense 


\section{METHOD}

The research was conducted in Gondang Legi, Prayungan, and Gondang Manis village, Bandar Kedungmulyo sub-district, Jombang regency. The data were collected by interviewing the farmers of Rose Apple. Descriptive analysis was employed by observing the conditions on the site and with the previous literature review and studies.

\section{RESULT AND DISCUSSION}

\section{Area Potential}

Bandar Kedungmulyo sub-district has a very strategic location, because it is located in the west-central part of Jombang regency and crossed the main road of SurabayaMadiun. The area is bordered with Perak sub-district in the east, Kediri in the east, Nganjuk in the west, and Megaluh in the north. Geographically, Bandar Kedungmulyo sub-district is located between 1120 06' $37^{\prime \prime}$ west longitude to $112010^{\prime} 30^{\prime \prime}$ east longitude and 07031 '39 " north latitude and 070 36' 49" south latitude, with an area of $32.49 \mathrm{~km}^{2}$. With an area of 3,250 ha, Bandar Kedung Mulyo district is a lowland with altitude $<700 \mathrm{~m}$ above sea level which has slope $<8 \%$. It has a hot soil temperature regime (Isohyperthermic) and a wet moisture regime (aquic) if it is administered. The climate condition in the area is moderate with 3-4 months monsoon and 5-6 months of dry season. In general, Bandar Kedung Mulyo district has a great potential for agricultural development.

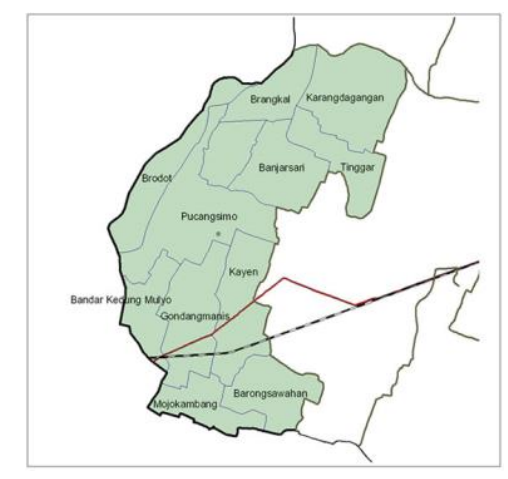

Figure 2.Map of Bandar Kedung Mulyo Subdistrict

\section{Population Potential}

Rose apple planting centers are scattered over East Java, West Java, Central Java and Yogyakarta. Rose apple does not yet become a commodity that is developed to plantation scale; it is generally grown as home garden plant only. In Java island, it is estimated that the amount of trees reaches 879,533 (BAPPENAS, 2000).

Jombang Regency has not been said to be the center of Rose Apple production, but with the characteristic that can arise because the influence of geographical and climate (environment) factors can support the increase of farmer's income and prosperity. Based on table 1, the number of trees in Jombang reaches 942 trees; they are scattered over 3 villages in Bandar Kedungmulyo sub- district. When compared to the estimated number of trees in East Java, Jombang only provides $0.11 \%$ of them. The number is actually not much, but with a proper management and a potential location, Syzygium malaccense will have a major impact on society.

Table 1. Number of rose appletree in Bandar Kedungmulyo District

\begin{tabular}{lccc}
\hline Village & $\begin{array}{l}\text { Number } \\
\text { of farmer }\end{array}$ & $\begin{array}{l}\text { Number } \\
\text { of tree }\end{array}$ & Average \\
\hline $\begin{array}{l}\text { Gondang } \\
\text { Legi }\end{array}$ & 18 & 369 & 20,5 \\
Prayugan & 62 & 295 & 4,76 \\
Gondang & 99 & 278 & 2,8 \\
Manis & & 942 & \\
Total & 179 & & \\
\hline
\end{tabular}

\section{Production Potential}

Rose apple fruit can be harvested twice a year, with the second harvest only $50 \%$ of the first harvest. The productivity of Cianjur's red rose apple was ranging from 12.48 to 15.6 tons/season/ha or $18.72-23.4$ tons/year/ha. With a population per ha of 156 trees, the productivity per tree was $120-150 \mathrm{~kg} /$ tree/year. The productivity began to decline when the plants reached the age of 30years-old (BAPPENAS, 2000). The result showed that Rose Apple in Jombang has the potential to harvest 3 times in a year with the average of $100-200 \mathrm{~kg} / \mathrm{tree} / \mathrm{year}$ production potential. This is relatively lower than the production potential in other areas. The average farmers have not cultivated to obtain the best possible results so that production will increase if there is an improvement on the cultivation. Therefore, if the production of Rose Apple in Jombang can be optimized then the total population of existing trees can produce 113.04 - 141.30 $\mathrm{kg} /$ year.

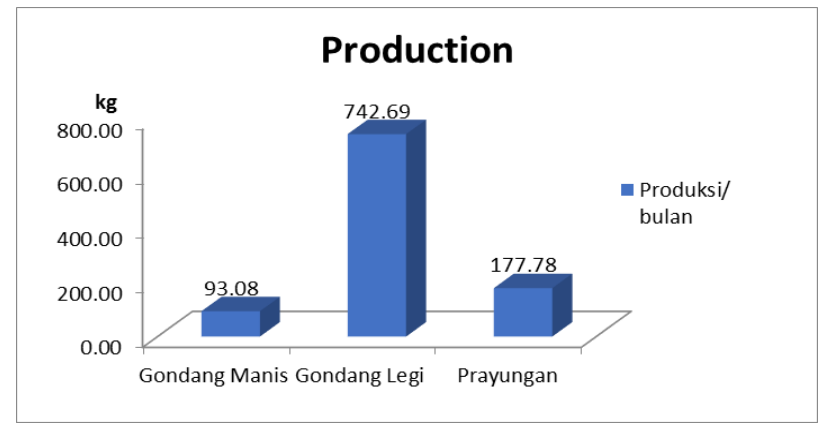

Figure 3 Guava production potential in Gondang Manis Village

The crops of Rose Apple production per year in 3 potential hamlets in Gondang Manis Village is presented on the graph in figure 3. The highest production was in Gondang Manis Village. It is according to the largest population potential in the Gondang Legi hamlet which is 369 trees. Besides, the potential of Rose Apple production in Gondang Legi hamlet is also higher than 2 other hamlets. The average farmer has more than 20 trees and has done the cultivation process that is fertilizing for 
Table 2. Analysis of the feasibility of processed food business based on watery Rose Apple

\begin{tabular}{lcccc}
\hline Product & $\begin{array}{l}\text { Jam(cup } \\
\text { @ } 125 \mathrm{ml})\end{array}$ & $\begin{array}{l}\text { Syrup } \\
\text { @60ml) }\end{array}$ & $\begin{array}{l}\text { (bottle } \\
\text { Pie/cake(pack } \\
\text { @350gr) }\end{array}$ & $\begin{array}{c}\text { Rose apple stick } \\
\text { (pouch @350gr) }\end{array}$ \\
\hline Number* & 20 & 10 & 20 & 30 \\
Unit price (IDR) & 6.000 & 16.000 & 7.500 & 7.000 \\
Income (IDR) & 120.000 & 160.000 & 150.000 & 210.000 \\
Fix cost (IDR) & 28.894 & 55.630 & 31.498 & 42.783 \\
Variable cost (IDR) & 51.750 & 87.250 & 77.150 & 127.200 \\
Total cost (IDR) & 80.644 & 142.880 & 108.648 & 169.983 \\
profit (IDR) & 39.356 & 7.120 & 41.352 & 40.017 \\
HPP (IDR) & 40.032 & 14.288 & 5.432 & 5.666 \\
\hline R/C & 1,49 & 1,12 & 1,38 & 1,24 \\
\hline
\end{tabular}

Source : Roesali, et.al. (2007)

crops so that the average production can reach more than $100 \mathrm{~kg} /$ tree/year.

4. Economic potential

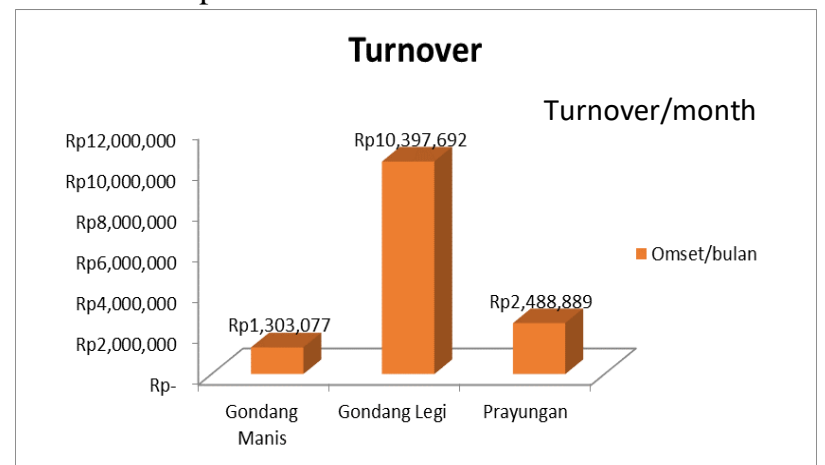

Figure 4 Sales turnover of rose apple Gondang Manis Village

The results of turnover research for the production of fresh fruit are presented in the graph in Figure 4. The results showed that the highest turnover is in Gondang Legi hamlet, with an average of Rp.10.000 per kg of total turnover of each tree, with an average production of 100$200 \mathrm{~kg}$ will be generated turnover Rp.1.000.000 up to Rp. 2.000.000,-. A premium fruit worth Rp.17.000 per $\mathrm{kg}$, it is the fruit produced by the process of cultivation and grading so that the turnover can reach $\mathrm{Rp}$. 3.400.000,-/ tree/ year.

Agricultural products diversification is an important mechanism for economic growth. These opportunities depend on diversification products and farmers' responses to the opportunities. Agricultural diversification can be facilitated by technological breakthroughs and or by demand policy (FAO, 2002). Research on feasibility analysis based on product diversification conducted by Roesali, et al (2007), some products are produced in table 2 used raw materials of watery Rose Apple. A processed food has an $\mathrm{R} / \mathrm{C}$ value of more than 1 , which means profitable. The results are also supported by the acceptability of products by consumers through organoleptic tests; which the results are well-received. Based on that, in an effort to improve the prosperity of Rose Apple farmers, it is done by multiplying the economic potential, through the development of product diversification.

Gondang Manis Rose Apple can be processed into utilitarian food product because of the rich of vitamin $\mathrm{C}$ and anti oxidant. The examples of processed products are juice, syrup, jam, jelly and ice cream. $1 \mathrm{~kg}$ of fruit can produce 400 cups of $100 \mathrm{ml}$ of juice with a price of Rp. 2.000 , - each cup. The income generated by the farmers from 1 tree increased $135 \%$ to $\mathrm{Rp} 8,000,000$. The business also absorbs the local labor, especially women, and improves the business capacity of BUMDES (villageowned enterprises)

\section{CONCLUSION}

It can be concluded from the result of that Gondang Rose Apple has a potential to be developed in Gondang Manis village with the transition of technology cultivation and product diversification. The production potential can reach $200 \mathrm{~kg} /$ tree/year with the price of Rp $17.000 / \mathrm{kg}$ with the turnover of Rp. 3,400,000, - .

Product diversification can increase the farmer income by $135 \%$ or Rp.8.000.000, -. As well as increase the absorption of female labor and the business capacity of village-owned enterprises

\section{REFERENCES}

[1]. Augusta, I.M., Resende, J.M., Borges, S.V., Maia, M.C.A., Couto, M.A.P.G. Caracterizac, ,ão fi 'sica e qui 'mica da casca e polpa de jambo vermelho (Syzygium malaccensis, (L.) Merryl \& Perry). Cie^nc. Tecnol. Aliment. 30, 928932. 2010

[2]. BAPPENAS, JAMBU BOL ( Syzygium malaccense L. ) Sumber : Sistim Informasi Manajemen Pembangunan di Perdesaan, Jakarta. 2000

[3]. Batista A. G., Silva J. K.da a, Cinthia B., Cazarin B., Biasoto A. C. T., Sawaya A. C. H. F., Prado A., Marcelo., Júnior M. R. M.,2017. Red-jambo (Syzygium malaccense): Bioactive compounds in 
fruits and leaves, LWT - Food Science and Technology 76 (2017) 284e291

[4]. FAO. Smallholder Farmers in India: Food Security and Agricultural Policy. Regional Office for Asia and the Pacific Bangkok, Thailand. 2002

[5]. Fernandes F. A. N. and Rodrigues S. JamboSyzygium malaccens. Exotic FruitsReference Guide, Pages 245-249. 2018

[6]. Martin, F.W., Campbell, C.W., Ruberte, R.M. Perennial Edible Fruits of the Tropics: An Inventory. USDA Agricultural Research Service,Wa. 1987

[7]. Roessali W., Sasmoko P., Darwanto. Pemberdayaan Masyarakat melalui Pengolahan Jambu Merah Delima (Syzygium semarangense) di Kabupaten Demak. Agrokreatif., Vol 3 (2): 123-128. 2017 